\title{
Normocalcemic primary hyperparathyroidism
}

\author{
Hiperparatiroidismo normocalcêmico primário
}

John P. Bilezikian', Shonni J. Silverberg'

${ }^{1}$ Divisão de Endocrinologia, Departamento de Medicina, College of Physicians \& Surgeons, Columbia University, Nova Iorque, Estados Unidos
Correspondence to: John P. Bilezikian

Division of Endocrinology

Department of Medicine Columbia University, College of

Physicians \& Surgeons

630 W. 168th Street

10032 - New York, NY, United States jpb2@Columbia.edu

Received on Jan/19/2009 Accepted on Feb/28/2010

\section{SUMMARY}

Primary hyperparathyroidism is a common disorder of mineral metabolism characterized by incompletely regulated, excessive secretion of parathyroid hormone from one or more of the parathyroid glands. The historical view of this disease describes two distinct entities marked by two eras. When primary hyperparathyroidism was first discovered about 80 years ago, it was always symptomatic with kidney stones, bone disease and marked hypercalcemia. With the advent of the multichannel autoanalyzer about 40 years ago, the clinical phenotype changed to a disorder characterized by mild hypercalcemia and the absence of classical other features of the disease. We may now be entering a $3^{\text {rd }}$ era in the history of this disease in which patients are being discovered with normal total and ionized serum calcium concentrations but with parathyroid hormone levels that are consistently elevated. In this article, we describe this new entity, normocalcemic primary hyperparathyroidism, a forme fruste of the disease. Arq Bras Endocrinol Metab. 2010;54(2):106-9

Keywords

Normocalcemic hyperparathyroidism; calcium; bone disease

\section{SUMÁRIO}

O hiperparatiroidismo primário (HPTP) é uma doença comum caracterizada por uma regulação inadequada da secreção do paratormônio em uma ou mais glândulas paratiroides. Historicamente a doença pode ser dividida em duas eras. Quando o HPTP foi descoberto há 80 anos, era sempre sintomático com nefrolitíase, doença óssea e acentuada hipercalcemia. Com o advento das rotinas laboratoriais por autoanalisadores bioquímicos há 40 anos, o fenótipo clínico mudou para uma doença sintomaticamente leve na ausência daqueles achados clássicos. Está se entrando numa terceira era em que os pacientes são diagnosticados com calcemia normal na presença de níveis circulantes elevados do paratormônio. Neste artigo, descreve-se essa nova entidade, hiperparatiroidismo primário normocalcêmico, uma forma frusta da doença. Arq Bras Endocrinol Metab. 2010;54(2):106-9

Descritores

Hormônio da paratiroide; cálcio, hiperparatiroidismo

\section{DIAGNOSIS}

$\mathrm{P}$ rimary hyperparathyroidism is readily diagnosed by a reliable immunoassay for parathyroid hormone (PTH). In the context of hypercalcemia, an elevated level of PTH substantiates a hypersecretory state of one or more of the 4 parathyroid glands. The PTH level also helps to differentiate primary hyperparathyroidism from other causes of hypercalcemia. The most frequent other cause of hypercalcemia is malignancy in which PTH levels are characteristically suppressed. Currently available immunoradiometric assays (IRMA) for PTH do not always show frankly elevated levels of PTH but when the value is the upper range of normal, it too is an abnormal measurement in the presence of hypercalcemia. This is the case because the expected response of normal parathyroid glands to hypercalcemia is marked suppression. The clinical utility of the classic IRMA for PTH, which has been in general use in the United States and throughout the world for over 20 years (1), is clear, even though it is now known to measure lar- 
ge circulating PTH fragments in addition to the intact full-length molecule (2). A newer IRMA for PTH that measures only the full length PTH molecule (1-84) (24 ) is similarly useful in making this diagnosis.

Using the classical assay for PTH as well as the newer one, we and others began to observe patients, about 10 years ago, whose PTH was elevated but in whom the serum calcium concentration was consistently normal $(5,6)$.

\section{CLINICAL PRESENTATION}

In many specialized metabolic bone units, such as ours at Columbia University Medical Center, patients are referred because of concerns about skeletal abnormalities. Many of these individuals, for example, have osteoporosis or low bone density. Our complete evaluation includes a PTH level even if the serum calcium is within normal limits. It is in the context of this complete evaluation of patients, the majority of whom are referred for low bone mass, that the findings leading to a diagnosis of normocalcemic primary hyperparathyroidism were first observed. It is important to describe several points about this new form of primary hyperparathyroidism.

First, in the classic presentation of primary hyperparathyroidism, the characteristic biochemical hallmark, hypercalcemia is not always seen. From time to time, the serum calcium may be normal. However, most of the time, the serum calcium in these patients is elevated. It is important to distinguish the patient with hypercalcemia whose serum calcium can be normal occasionally from the entity that has surfaced more recently in which the serum calcium is always normal. The old literature, in fact, described some cohorts as "normocalcemic", while more careful inspection has shown that these patients were intermittently normocalcemic (7). Thus, the patients we are describing with normocalcemic primary hyperparathyroidism are distinct from primary hyperparathyroidism that presents with overt hypercalcemia, in which the serum calcium level can occasionally be normal.

Second, in normocalcemic primary hyperparathyroidism, the ionized calcium is also normal. The series of Monchik and Gorgun (8) would thus not meet the criteria of normocalcemic primary hyperparathyroidism because the vast majority of their patients had elevated ionized calcium levels.

Third, it is important to rule out causes for an elevated parathyroid hormone level apart from primary hyperparathyroidism. The most common cause of secondary elevations in parathyroid hormone is vitamin $\mathrm{D}$ deficiency. There is an inverse relationship between 25-hydroxyvitamin $\mathrm{D}$ (the storage form of vitamin $\mathrm{D}$ ) and PTH, so that at some level of 25-hydroxyvitamin D below normal, the parathyroid gland responds with increased synthesis and secretion of parathyroid hormone. The level of 25-hydroxyvitamin $\mathrm{D}$ at which this occurs is somewhere between 30 and $20 \mathrm{ng} / \mathrm{mL}$ $(9,10)$. If patients have levels of 25 -hydroxyvitamin D below $30 \mathrm{ng} / \mathrm{mL}$, a normal serum calcium can be associated with elevated PTH on that basis. If the cause of the elevated PTH level is low vitamin D, repletion with vitamin $\mathrm{D}$ would be associated with normalization of the PTH level. It should be noted, however, that occasionally when vitamin D deficiency is corrected, a normocalcemic patient becomes hypercalcemic and thus their presentation becomes that of traditional hypercalcemic primary hyperparathyroidism. In that instance, the normocalcemia was due to the Vitamin D deficiency. In addition to ruling out vitamin $\mathrm{D}$ insufficiency, it is important to rule out other causes of secondary elevations in PTH, among which the most important ones are hypercalciuria and reduced creatinine clearance $(<60 \mathrm{cc} / \mathrm{min})$.

\section{EPIDEMIOLOGY}

Very little is known about the epidemiology of normocalcemic primary hyperparathyroidism. Lundgren and cols. $(11,12)$ surveyed 5,202 postmenopausal women in Sweden between the ages of 55 and 75. Of the 109 individuals who were suspected either because of concomitant hypercalcemia and elevated levels of PTH, or elevations of either PTH or serum calcium, 17 of the 109 subjects (16\%) had normal serum calcium levels $(<9.9 \mathrm{mg} / \mathrm{dL})$ and elevated PTH. This subset included both those with vitamin $\mathrm{D}$ deficiency (which was not ruled out) and true normocalcemic PHPT, so we remain unsure of the epidemiology of the disease.

\section{PATHOPHYSIOLOGY}

Maruani and cols. (5) postulated in normocalcemic primary hyperparathyroidism, that there is resistance to target tissues. After an oral calcium load, normocalcemic subjects showed inadequate suppression of PTH when matched with a cohort of subjects with hypercalcemic primary hyperparathyroidism. For any amount of 
calcium entering the extracellular fluid, subjects with normocalcemic primary hyperparathyroidism had lower serum calcium levels than hypercalcemic individuals.

Another concept relevant to the pathophysiology of normocalcemic primary hyperparathyroidism is based upon the evolution of the hypercalcemic form. Rao and cols. (13) argued that the first detectable abnormality of the parathyroids in primary hyperparathyroidism should be an increase in the circulating PTH level. This first phase was postulated to be subclinical because in those days, PTH levels were virtually never obtained in normocalcemic subjects. Their hypothesis went on to state that the second phase of the evolution of primary hyperparathyroidism would be the clinical stage when hypercalcemia became overtly present. This attractive concept has become even more appealing as PTH levels were obtained in subjects with normal calcium levels and this cohort began to be identified. The hypothesis of Parfitt, Kleerekoper and Rao also carries with it the idea that a certain percentage of these patients should become hypercalcemic over time (see below).

\section{THE COLUMBIA EXPERIENCE}

Our group was one of the first to study in a systematic fashion normocalcemic primary hyperparathyroidism. Inclusion criteria were an elevated PTH (by IRMA $>65 \mathrm{pg} / \mathrm{m})$; normal serum calcium concentration (8.5-10.4 mg/dL) and a 25-hydroxyvitamin D level $>20 \mathrm{ng} / \mathrm{mL}(6,14)$. Exclusion criteria were any cause for secondary hyperparathyroidism (renal or liver disease, malabsorption, hypercalciuria), uncontrolled thyroid disease, or other metabolic bone disease. We evaluated 37 patients. Their average age was $59 \pm 2$ years. The breakdown of gender was $95 \%$ female: $5 \%$ male. Of the women $16 \%$ were premenopausal. As alluded to above, the majority of these individuals were referred to us for further evaluation of a target organ that could be affected by parathyroid disease. The percentages of involvement are given in parentheses: low bone mass $(73 \%)$; fracture (11\%); kidney stone $(5 \%)$. The average serum calcium concentration was $9.6 \pm 0.1 \mathrm{mg} / \mathrm{dL}$; the average PTH concentration was $93 \pm 5 \mathrm{pg} / \mathrm{mL}$ (nl: 10 $65 \mathrm{pg} / \mathrm{mL}$ ). The average 25-hydroxyvitamin D level was $33 \pm 1 \mathrm{ng} / \mathrm{mL}$. At all 3 sites, bone density was on average in the osteopenic range. Many individuals, however, had densitometric levels in the osteoporotic range. A full $50 \%$ of our subjects had an osteoporotic T-score at one skeletal site at least.
The concept of normocalcemic primary hyperparathyroidism includes the idea that some of these patients will become hypercalcemic over time. In our experience so far, with an average follow up of 4 years, $22 \%$ of our cohort has become hypercalcemic. Those with somewhat higher average serum calcium concentrations were more likely to become hypercalcemic as were those who were somewhat older. Evidence of disease progression was also seen in that a number of subjects were developed guidelines for parathyroid surgery (15). They included: fracture, kidney stone, osteoporotic T-scores. Sestamibi scans were positive in $62 \%$ of subjects. Surgery in 10 subjects who underwent parathyroidectomy include that traditional single parathyroid adenoma but also, double adenomas and 4-gland hyperplasia.

These data argue that a certain percentage of patients who have normocalcemic primary hyperparathyroidism will progress to overt hypercalcemic primary hyperparathyroidism, and are consistent with earlier reports of Lundgren and cols (11). It seems evident however that progression to hypercalcemia is not inevitable, nor is there any uniform time course for the development of hypercalcemia. Many of our subjects continue to show normal concentrations of the serum calcium.

\section{THE CONUNDRUM}

As the disease appears now to include a third phenotype, the history of primary hyperparathyroidism seems to argue that the disease has become milder over the years. We rarely see patients with the overt symptom complex and marked hypercalcemia of many decades ago (although it still occurs occasionally). The description of asymptomatic primary hyperparathyroidism is clearly a milder variant. This form of primary hyperparathyroidism, in fact, has been the subject of three workshops (15-17) in an effort to develop medical or surgical management guidelines. One might expect that patients with normocalcemic primary hyperparathyroidism would have the most mild and most asymptomatic form of the disease. However, from our experience it would appear that these patients actually have more involvement and are truly not even asymptomatic. The reason for this presentation is likely to be the referral bias of our series, in which patients are identified from a population already found to have a problem. We have now modified the original hypothesis of Rao and cols. (13) by suggesting that there are two forms of normocalcemic primary hyperparathyroidism. What we and others appear to have described 
so far are those who already have developed clinical features of the disease. It is distinctly possible that there is another cohort of subjects with normocalcemic primary hyperparathyroidism who are the forerunners of the asymptomatic disease that we typically see today. The way to detect these individuals would be to obtain samples for calcium and parathyroid hormone from a cohort that is not referred for any skeletal issues. Samples obtained from such individuals may well lead to the identification of individuals who are best described as asymptomatic normocalcemic primary hyperparathyroidism.

Do the guidelines for the Management of Asymptomatic Primary Hyperparathyroidism apply to normocalcemic primary hyperparathyroidism?

At the time of the Third International Workshop on the Management of Asymptomatic Primary Hyperparathyroidism (17) the entity of normocalcemic primary hyperparathyroidism was recognized officially. The expert panel however stated that since so little is known about this form of the disease, the guidelines for the management of asymptomatic classic primary hyperparathyroidism could not be applied with confidence. We feel that this advice is prudent. We also feel that subjects should be monitored regularly for progression of their disease. It is clear that if the disease is worsening, then a proactive, surgical approach would seem to be appropriate.

Acknowledgments: this work was supported in part by a grant from the National Institutes of Health (NIDDK 32333 ).

Disclosure: no potential conflict of interest relevant to this article was reported.

\section{REFERENCES}

1. Lepage R, Roy L, Brossard JH, Rousseau L, Dorais C, Lazure C, et al. A non (1-84) circulating parathyroid hormone (PTH) fragment interferes significantly with intact PTH commercial assay measurements in uremic samples. Clin Chem. 44:805-9.

2. D'Amour P, Brossard J-H, Rousseau L, et al. Structure of non-(184) PTH fragments secreted by parathyroid glands in primary and secondary hyperparathyroidism. Kidney Int. 2005;68:998-1007.
3. Gao P, Scheibel S, D'Amour P, John MR, Rao SD, Schmidt-Gayk H, et al. Development of a novel immunoradiometric assay exclusively for biologically active whole parathyroid hormone 1-84. Implications for improvement of accurate assessment of parathyroid function. J Bone Miner Res. 2001;16:605-14.

4. Silverberg SJ, Brown I, LoGerfo P, Gao P, Cantor T, Bilezikian JP. Clinical utility of an immunoradiometric assay for whole PTH (1-84) in primary hyperparathyroidism. J Clin Endocrinol Metab. 2003;88:4725-30.

5. Maruani G, Hertig A, Paillard M, Houillier P. Normocalcemic primary hyperparathyroidism: evidence for a generalized target-tissue resistance to parathyroid hormone. J Clin Endocrinol Metab. 2003;88:4641-8.

6. Silverberg SJ, Bilezikian JP. "Incipient" primary hyperparathyroidism: a "forme fruste" of an old disease. J Clin Endocrinol Metab. 2003;88:5348-52.

7. Wills MR, Pak CY, Hammond WG, Bartter FC. Normocalcemic primary hyperparathyroidism. Am J Med. 1967;47:384-91.

8. Monchik JM, Gorgun E. Normocalcemic hyperparathyroidism in patients with osteoporosis. Surgery. 2004;136:1242-6.

9. Heaney RP. The vitamin $D$ requirement in health and disease. $J$ Steroid Biochem Molec Biol. 2005;97:13-9.

10. Holick MF. Vitamin D deficiency. N Eng J Med. 2007;357:266-81

11. Lundgren E, Hagstrom EG, Lundin J, Winnerback MB, Roos J, Ljunghall $S$, et al. Primary hyperparathyroidism revisited in menopausal women with serum calcium in the upper normal range at population based screening 8 yrs ago. World J Surg. 2002;26:931-6.

12. Tordjman KM, GreenmanY, Osher E, Shenkerman G, Sern N. Characterization of normocalcemic primary hyperparathyroidism. Am J Med. 2004;117:861-3.

13. Rao DS, Wilson RJ, Kleerekoper M, Parfitt AM. Lack of biochemical progression or continuation of accelerated bone loss in mild asymptomatic primary hyperparathyroidism: evidence for biphasic disease course. J Clin Endocrinol Metab. 1988;67:1294-8.

14. Lowe H, McMahon DJ, Rubin MR, Bilezikian JP, Silverberg SJ. Normocalcemic primary hyperparathyroidism: further characterization of a new clinical phenotype. J Clin Endocrinol Metab. 2007;92:3001-5.

15. Bilezikian JP, Potts JT Jr, El-Hajj Fuleihan G, Kleerekoper M, Neer R, et al. Summary statement from a workshop on asymptomatic primary hyperparathyroidism: a perspective for the 21 st century. $J$ Bone Min Res. 2002;17(suppl 2):N2-11. J Clin Endocrinol Metab. 2002;87:5353-61.

16. National Institutes of Health: Consensus Development Conference Statement on Primary Hyperparathyroidism. J Bone Miner Res. 1991;6:S9-13.

17. Bilezikian JP, Khan A, Potts JT Jr. Guidelines for the management of asymptomatic primary hyperparathyroidism: summary statement from the third international workshop. J Clin Endocrinol Metab. 2009;94:335-9. 